\title{
Simple, responsive and cost effective simultaneous quantification of Ga(III) and In(III) in environmental water samples**
}

\author{
Małgorzata Grabarczyk*(i) and Marzena Adamczyk (1) \\ Maria Curie-Skłodowska University, Chemical Faculty, Department of Analytical Chemistry and Instrumental Analysis, \\ M. Curie-Skłodowskiej 3, 20-031 Lublin, Poland
}

Received August 21, 2018; accepted December 30, 2018

\begin{abstract}
The simultaneous determination of $\mathrm{Ga}(\mathrm{III})$ and In(III) in environmental water samples was described. The procedure was based on adsorptive stripping voltammetry using an in situ plated bismuth film electrode as a working electrode. In order to obtain low detection limits and satisfactory separations of gallium and indium peaks on the voltammogram, cupferron was used as a complexing agent. The optimum composition of the supporting electrolyte was found to be: $0.1 \mathrm{~mol}^{-1}$ acetate buffer ( $\mathrm{pH}=5.0), 2 \times 10^{-4} \mathrm{~mol}^{-1}$ cupferron, $2 \times 10^{-4} \mathrm{~mol} \mathrm{l}^{-1} \mathrm{Bi}(\mathrm{III})$, optimal voltammetric parameters were found to be: accumulation potential $-0.9 \mathrm{~V}$, accumulation time $60 \mathrm{~s}$. The linear range of $\mathrm{Ga}(\mathrm{III})$ as well as In(III) was observed over a concentration range from $2.5 \times 10^{-8} \mathrm{~mol} \mathrm{l}^{-1}$ to $1.5 \times 10^{-6} \mathrm{~mol} \mathrm{l}^{-1}$. The method was satisfactorily applied to the simultaneous quantification of gallium and indium in environmental water samples. This facilitated a promising application of the recommended procedure for monitoring the environment, which is necessary to evaluate the soil-plant system.

Keywords: gallium(III), indium(III), trace analysis, environmental water samples
\end{abstract}

\section{INTRODUCTION}

The need for procedures for the simultaneous determination of $\mathrm{Ga}(\mathrm{III})$ and $\mathrm{In}(\mathrm{III})$ results from the fact that both gallium and indium have recently gained much interest and are essential in high-technology industries, mainly for manufacturing semiconductor and electronic devices. Gallium and its compounds are also used in the production of low-melting alloys and as a specialized mirror coating in high-temperature thermometers (Choua et al., 2008; Font et al., 2007; Zhao et al., 2012). Indium is primarily used in thin-film coatings that are prevalent in liquid crystal display screens (LCDs) in computers, game consoles, and CD/DVD players, flat panel displays, solar cells, and

*Corresponding author e-mail: mgrabarc@poczta.umcs.lublin.pl electroluminescent lamps. Also, indium oxide is used in solar cells and electroluminescent lamps (Alfantazi et al., 2003; Merian et al., 2004). Recent reports mention the use of alloys composed of gallium and indium for 3D printing with liquid metals. These alloys make it possible to create structures by piling drops on top of each other and thereby forming specific shapes (Daalkhaijav et al., 2018; Zatopa et al., 2018).

The soil-plant system is largely dependent on the quality of the environmental waters, so monitoring its quality is a basic issue. This monitoring process requires, among other things, the control of the content of anthropogenic metals in environmental waters. At present, due to the growth of high-technology industries, multiple metals enter the environment, among them gallium and indium. As both gallium and indium are used for similar purposes, they often get into the environment from the same anthropogenic sources and consequently, they are frequently present together in environmental waters. Therefore, procedures allowing the simultaneous determination of gallium and indium are very desirable.

The simultaneous determination of Ga(III) and $\mathrm{In}$ (III) is an important issue as evidenced by the considerable volume of literature data published both, in the past (Hayashibe et al., 1989; Orians and Boyle, 1993; Prat et al., 1996; Zaki and El-Didamony, 1988) and in the 21st century (BermejoBarrera et al., 2001; Liu et al., 2012; Medvecky and Briancin, 2002; Saberyan et al., 2009; Singh et al., 2001). In the vast majority of the procedures described, spectrometric methods were used, such as electrothermal atomization 
atomic absorption spectrometry (ET-AAS) (Hayashibe et al., 1989), inductively coupled plasma mass spectrometry (ICP-MS) (Orians and Boyle, 1993), or inductively coupled plasma optical emission spectrometry (ICP-OES) (Liu et al., 2012). Only one voltammetry procedure, namely anodic stripping voltammetry was applied for the simultaneous determination of gallium and indium (Medvecky and Briancin, 2002). Given the fact that ET-AAS, ICP-MS and ICP-OES require expensive instrumentation, the voltammetric procedure seems to be an attractive alternative for the simultaneous determination of $\mathrm{Ga}(\mathrm{III})$ and $\mathrm{In}(\mathrm{III})$, therefore the creation of such a procedure is highly desirable. Among the stripping voltammetric methods we can distinguish between anodic stripping voltammetry (ASV) and adsorptive stripping voltammetry (AdSV), where AdSV has preferable characteristics for obtaining a lower detection limit. That being the case, our research will be aimed at developing an original AdSV procedure for the simultaneous determination of gallium and indium.

An important issue in voltammetric measurement is the choice of working electrode. At present there is an unwarranted focus on the mercury-free electrode, as it is more eco-friendly for laboratory experiments. From the recently proposed electrodes used in voltammetry, the bismuth film electrodes (BiFE) were shown to be attractive alternatives to mercury electrodes both in anodic as well as in adsorptive stripping analysis (Królicka et al., 2002; Petovar et al., 2018; Urbanova et al., 2010; Wang et al., 2000; Wang et al., 2001; Zidaric et al., 2018). These electrodes may be prepared both in ex situ and in situ mode, the latter one especially can boast both speed and simplicity of preparation. Moreover, as has been repeatedly described in the literature, the BiFE allows one to obtain high sensitivity and provides the possibility of conducting measurements in the presence of oxygen. Due to this, the total measurement time is shorter because it is not necessary to deoxygenate the solution (Grabarczyk and Wasąg, 2015; Królicka et al., 2003; Wasąg and Grabarczyk, 2016; Węgiel et al., 2017).

In view of the above, we decided to exploit the in situ plated bismuth film electrode as both a responsive and easily prepared working electrode for the simultaneous determination of $\mathrm{Ga}$ (III) and $\mathrm{In}$ (III) by adsorptive stripping voltammetry.

\section{MATERIALS AND METHODS}

Stock standard solutions of $1 \mathrm{~g} \mathrm{l}^{-1} \mathrm{Ga}(\mathrm{III})$ and $1 \mathrm{~g} \mathrm{l}^{-1}$ In(III) were obtained from Merck (Darmstadt, Germany) and Fluka (Buchs, Switzerland), respectively. The solutions of $\mathrm{Ga}$ (III) and $\mathrm{In}(\mathrm{III})$ of lower concentrations were prepared daily by dilution of the stock solution as required. A stock standard solution of $1 \mathrm{~g} \mathrm{l}^{-1}$ of $\mathrm{Bi}(\mathrm{III})$ and cupferron (N-nitrosophenylhydroxylamine ammonium salt) were obtained from Merck (Darmstadt, Germany). A solution of $1 \times 10^{-2} \mathrm{~mol} \mathrm{l}^{-1}$ of cupferron was prepared every day by dissolving $0.0155 \mathrm{~g}$ of the reagent in water in a $10 \mathrm{ml}$ volumetric flask. The acetate buffer $\left(1 \mathrm{~mol} \mathrm{l}^{-1}\right)$ was prepared from Suprapur grade $\mathrm{CH}_{3} \mathrm{COOH}$ and $\mathrm{NaOH}$ obtained from Merck. Amberlite XAD-7 resin was obtained from Sigma (St. Louis, MO, USA) and was washed four times with triply distilled water and dried at a temperature of $50^{\circ} \mathrm{C}$ before use. All solutions were made using triply distilled water.

All voltammetric measurements were carried out using a $\mu$ Autolab analyzer (Utrecht, the Netherlands). The threeelectrode system included a glassy carbon (GC) disc of $1 \mathrm{~mm}$ diameter as a working electrode, platinum wire as an auxiliary electrode and an $\mathrm{Ag} / \mathrm{AgCl}$ electrode as a reference electrode. A glassy carbon electrode was polished daily on a 2000 grit sandpaper and next using $0.3 \mu \mathrm{m}$ alumina slurry on a Buehler polishing pad. All experiments were carried out at room temperature.

The standard voltammetric measurement was carried out as follows. To the analyzed sample, or a synthetic sample (containing suitable concentrations of $\mathrm{Ga}$ (III) and In(III) diluted in triply distilled water), $1 \mathrm{ml}$ of $1 \mathrm{~mol} \mathrm{l}^{-1}$ acetate buffer $\mathrm{pH}=5.0,400 \mu \mathrm{l}$ of $1 \mathrm{~g} \mathrm{l}^{-1} \mathrm{Bi}(\mathrm{III}), 200 \mu \mathrm{l}$ of $1 \times 10^{-2} \mathrm{~mol} \mathrm{l}^{-1}$ cupferron and an adequate volume of triply distilled water was added, so that the final volume of the solution was $10 \mathrm{ml}$. The standard measuring procedure was performed using differential pulse adsorptive stripping voltammetry.

The measurement consisted of three stages:

- Electrochemical cleaning of the GC electrode by applying successive potentials: $-1.3 \mathrm{~V}$ for $15 \mathrm{~s}$ and $0.2 \mathrm{~V}$ for $15 \mathrm{~s}$. During that time first the remains from the previous measurement were reduced to the metallic state and then they were removed from the electrode.

- Deposition step: at $-0.9 \mathrm{~V}$ for $30 \mathrm{~s}$. During that time the bismuth film electrode was deposited on the GC electrode and the $\mathrm{Ga}(\mathrm{III})$-cupferron and $\mathrm{In}(\mathrm{III})$-cupferron complexes were accumulated simultaneously, whilst stirring the solution with a magnetic stirring bar.

- Recording of the voltammogram: after a rest period of $5 \mathrm{~s}$, the potential was swept from $-0.65 \mathrm{~V}$ to $-1.15 \mathrm{~V}$, the scan rate and the pulse height were $100 \mathrm{mV} \mathrm{s}^{-1}$ and $100 \mathrm{mV}$, respectively.

\section{RESULTS AND DISCUSSION}

As was shown in earlier investigations, $\mathrm{Ga}(\mathrm{III})$ and In(III) form electrochemically active complexes with cupferron, which makes the voltammetric determination of these elements possible with a low detection limit (Grabarczyk and Wardak, 2014; Grabarczyk and Wasąg, 2015; Grabarczyk and Wasąg, 2016; Wasąg and Grabarczyk, 2016). This study will focus on the development of an original adsorptive voltammetric procedure for the simultaneous determination of gallium and indium. In order to obtain the best shape and separation of gallium and indium peaks on one voltammogram that would provide optimum 
conditions, we studied the influence of various experimental parameters (e.g. $\mathrm{pH}$, cupferron concentration, conditions of bismuth film formation and the adsorption of gallium and indium complexes onto it).

Based on literature data, an acetate buffer was chosen as a supporting electrolyte as it was considered to be the most suitable option for both $\mathrm{Ga}$ (III)-cupferron and In(III)cupferron complex formation (Grabarczyk and Wardak, 2014; Grabarczyk and Wasąg, 2015; Grabarczyk and Wasąg, 2016; Wasąg and Grabarczyk, 2016). The pH of the acetate buffer was changed from 3 to 5.5 and its influence on gallium and indium peak currents is presented in Fig. 1. Another factor affecting the selection of $\mathrm{pH}$ is the separation of peaks on the voltammogram. It was noted that the $\mathrm{pH}$ only has a slight influence over the separation of the analyzed peaks, and with a more acidic solution the separation of peaks deteriorates to an insignificant extent. Summing up the above data, a $\mathrm{pH}$ equal to $5.0 \pm 0.1$ was proposed as the optimal one.

The influence of the concentration of the supporting electrolyte on the gallium and indium peak currents was tested in the range $0.05-0.2 \mathrm{~mol} \mathrm{l}^{-1}$. It was found that the change in the buffer concentration in the tested range did not affect the peak currents of gallium and indium, thus a concentration of acetate buffer equal to $0.1 \mathrm{~mol} \mathrm{l}^{-1}$ was selected as the optimal concentration.

The experiments were carried out using solutions containing $2 \times 10^{-7} \mathrm{~mol}^{-1} \mathrm{Ga}(\mathrm{III})$ and $\mathrm{In}(\mathrm{III}), 0.1 \mathrm{~mol}^{-1}$ acetate buffer ( $\mathrm{pH}=5.0), 2 \times 10^{-4} \mathrm{~mol} \mathrm{l}^{-1} \mathrm{Bi}(\mathrm{III})$ and a varying concentration of cupferron. The measurements performed showed that the concentration of cupferron did not affect the separations between the peaks of gallium and indium. Only with an increasing concentration of cupferron do both peaks move towards more negative potentials. That being the case, only the influence of cupferron concentration on peak currents was taken into account. For both elements it was observed that the peak currents increased upon increasing the cupferron concentration to $2 \times 10^{-4} \mathrm{~mol}^{-1}$ and then it remained unchanged up to a concentration of $4 \times 10^{-4} \mathrm{~mol}^{-1}$ at a higher concentration they decreased slightly (Fig. 2).

The Bi(III) concentration used for the in situ formation of the bismuth film was found to affect the peak height for gallium and indium. The AdSV peak current of $2 \times 10^{-7} \mathrm{~mol}$ $\mathrm{I}^{-1} \mathrm{Ga}(\mathrm{III})$ and $\mathrm{In}(\mathrm{III})$ in the presence of $2 \times 10^{-4} \mathrm{~mol}^{-1}$ cupferron and $0.1 \mathrm{~mol} \mathrm{l}^{-1}$ acetate buffer $(\mathrm{pH}=5.0)$ was examined for its dependence on $\mathrm{Bi}(\mathrm{III})$ concentration over the range of $5 \times 10^{-6}$ and $5 \times 10^{-4} \mathrm{~mol} \mathrm{l}^{-1}$. The obtained results are presented in Fig. 3. It may be observed that the bismuth concentration of $2 \times 10^{-4} \mathrm{~mol} \mathrm{l}^{-1}$ is the most suitable one for the simultaneous determination of gallium and indium in one measurement.

In order to simplify all measurements we proposed one accumulation step, during which, the formation of the in situ bismuth film electrode and the adsorption of Ga(III)cupferron and $\operatorname{In}(\mathrm{III})$-cupferron complexes take place

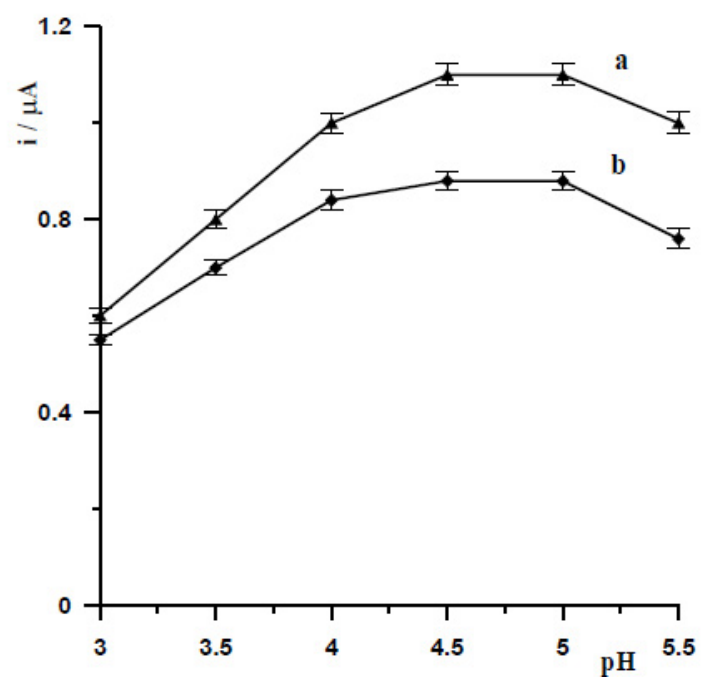

Fig. 1. Influence of $\mathrm{pH}$ on the indium (a) and gallium (b) peak current. Concentrations of In(III) and Ga(III) $2 \times 10^{-7} \mathrm{~mol} \mathrm{l}^{-1}, 2 \times$ $10^{-4} \mathrm{~mol} \mathrm{l}^{-1}$ cupferron, $2 \times 10^{-4} \mathrm{~mol} \mathrm{l}^{-1} \mathrm{Bi}(\mathrm{III})$. The accumulation potential and time are $-0.9 \mathrm{~V}$ and $30 \mathrm{~s}$, respectively.

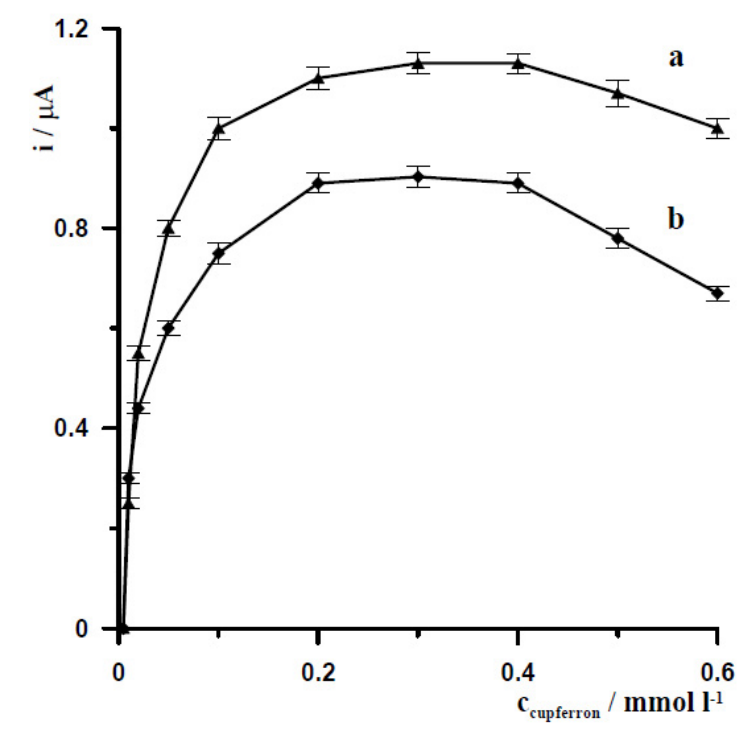

Fig. 2. Influence of cupferron concentration on the indium (a) and gallium (b) peak current. Concentrations of In(III) and Ga(III) $2 \times 10^{-7} \mathrm{~mol} \mathrm{l}^{-1}, 0.1 \mathrm{~mol} \mathrm{l}^{-1}$ acetate buffer $(\mathrm{pH}=5.0), 2 \times 10^{-4} \mathrm{~mol} \mathrm{l}^{-1}$ $\mathrm{Bi}(\mathrm{III})$. The accumulation potential and time are $-0.9 \mathrm{~V}$ and $30 \mathrm{~s}$, respectively.

simultaneously. The influence of potential values on the peak currents of gallium and indium, and the separation of peaks was examined over a range from $-0.65 \mathrm{~V}$ to $-1.1 \mathrm{~V}$. It was observed that by changing the potential in a negative direction, the separation of gallium and indium peaks increased. This dependence is illustrated in Fig. 4 which presents the voltammograms recorded for an accumulation potential equal to $-0.65 \mathrm{~V}$ and $-0.9 \mathrm{~V}$ for a solution containing $5 \times 10^{-7} \mathrm{~mol} \mathrm{l}^{-1} \mathrm{Ga}(\mathrm{III})$ and $\mathrm{In}(\mathrm{III})$. With regard to the peak currents, in the range of the accumulation potential from -0.65 to $-0.9 \mathrm{~V}$ the peak currents remained unchanged 


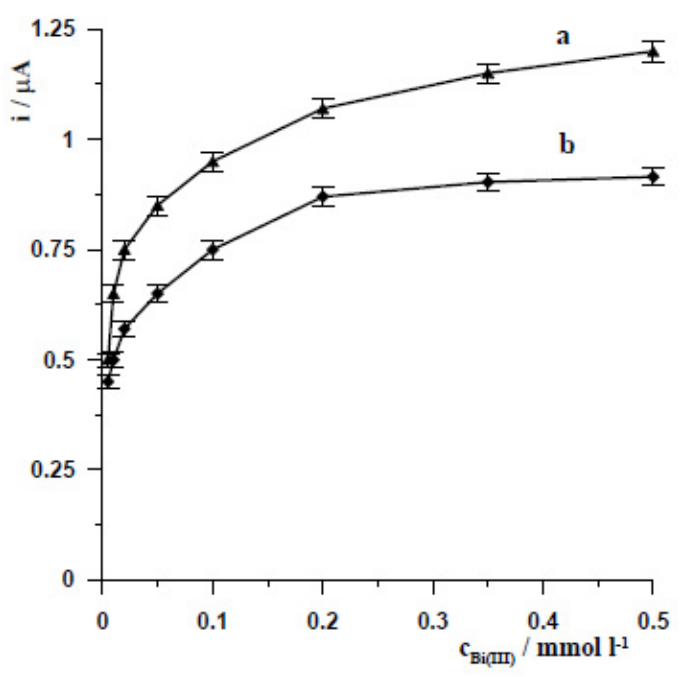

Fig. 3. Influence of the concentration of Bi(III) on the peak current of indium (a) and gallium (b). Concentration of In(III) and $\mathrm{Ga}$ (III) $2 \times 10^{-7} \mathrm{~mol} \mathrm{l}^{-1}, 0.1 \mathrm{~mol} \mathrm{l}^{-1}$ acetate buffer $(\mathrm{pH}=5.0), 2 \times 10^{-4}$ mol $1^{-1}$ cupferron. The accumulation potential and time are $-0.9 \mathrm{~V}$ and $30 \mathrm{~s}$, respectively.

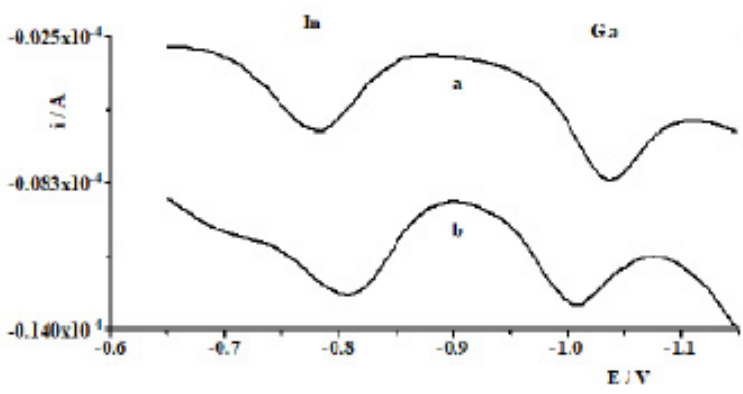

Fig. 4. Voltammograms recorded at different accumulation potentials $-0.9 \mathrm{~V}$ (a) and $-0.65 \mathrm{~V}$ (b). Concentration of In(III) and Ga(III) $5 \times 10^{-7} \mathrm{~mol} \mathrm{l}^{-1}, 0.1 \mathrm{~mol} \mathrm{l}^{-1}$ acetate buffer $(\mathrm{pH}=5.0), 2 \times 10^{-4} \mathrm{~mol} \mathrm{l}^{-1}$ cupferron $2 \times 10^{-4} \mathrm{~mol} \mathrm{l}^{-1} \mathrm{Bi}(\mathrm{III})$. The accumulation time was $30 \mathrm{~s}$.

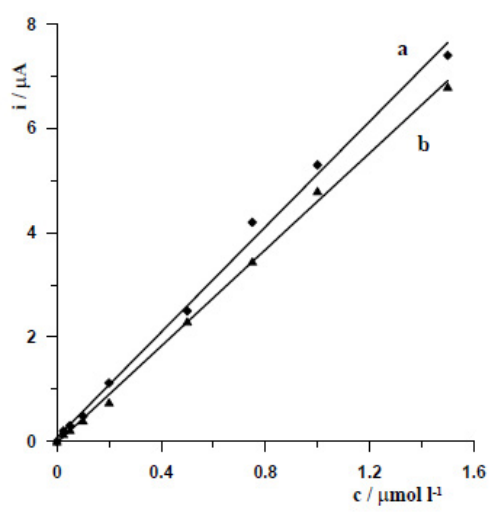

Fig. 5. Calibration curves for In(III) (a) and $\mathrm{Ga}$ (III) (b) were obtained under standard conditions. Supporting electrolyte: 0.1 mol l-1 acetate buffer $(\mathrm{pH}=5.0), 2 \times 10^{-4} \mathrm{~mol} \mathrm{l}^{-1}$ cupferron, $2 \times 10^{-4}$ $\mathrm{mol} \mathrm{l} \mathrm{l}^{-1} \mathrm{Bi}(\mathrm{III})$. The accumulation potential and time were $-0.9 \mathrm{~V}$ and $30 \mathrm{~s}$, respectively. and, as the potential value changed in the negative direction, a gradual decrease of peak currents was observed. An optimum accumulation potential of $-0.9 \mathrm{~V}$ was chosen in the proposed procedure.

The accumulation time was tested in the range of $0-180$ $\mathrm{s}$ at the accumulation potential equal to $-0.9 \mathrm{~V}$. The values of voltammetric peak currents increased almost linearly with the accumulation time to $30 \mathrm{~s}$ both for gallium and indium.

Linear calibration graphs show the concentration range of $2.5 \times 10^{-8} \mathrm{~mol} \mathrm{l}^{-1}$ to $1 \times 10^{-6} \mathrm{~mol} \mathrm{l}^{-1}$ for $\mathrm{Ga}$ (III) and In(III), and they can be described by the following calibration equations: $\mathrm{y}=4.98 \mathrm{x}-0.08(\mathrm{R}=0.997)$ for $\mathrm{Ga}(\mathrm{III})$ and $\mathrm{y}$ $=5.23 \mathrm{x}+0.07(\mathrm{R}=0.997)$ for $\mathrm{In}(\mathrm{III})$, where $\mathrm{y}$ and $\mathrm{x}$ are the peak current $(\mu \mathrm{A})$ and metal concentration $\left(\mu \mathrm{mol} \mathrm{l}^{-1}\right)$, respectively (Fig. 5). The detection limits estimated from 3 times the standard deviation of low Ga(III) and In(III) concentrations and accumulation time of $30 \mathrm{~s}$ were approximately $9.7 \times 10^{-9} \mathrm{~mol} \mathrm{l}^{-1}$ and $8.8 \times 10^{-9} \mathrm{~mol} \mathrm{l}^{-1}$, respectively. The relative standard deviation (RSD) from six determinations at concentrations of $5 \times 10^{-8} \mathrm{~mol} \mathrm{l}^{-1}$ of $\mathrm{Ga}$ (III) was $4.1 \%$ and at $1 \times 10^{-8} \mathrm{~mol} \mathrm{l}^{-1}$ of In(III) it was $3.9 \%$. All of the measurements were performed under the selected conditions: $0.1 \mathrm{~mol} \mathrm{l}^{-1}$ acetate buffer $(\mathrm{pH}=5.0), 2 \times 10^{-4} \mathrm{~mol} \mathrm{l}^{-1}$ cupferron, $2 \times 10^{-4} \mathrm{~mol} \mathrm{l}^{-1} \mathrm{Bi}(\mathrm{III})$, deposition potential of $-0.9 \mathrm{~V}$, deposition time of $30 \mathrm{~s}$.

The quality of water affects the soil-plant system, therefore the purpose of our research was the practical application of a methodically developed procedure for the simultaneous determination of $\mathrm{Ga}$ (III) and $\mathrm{In}(\mathrm{III})$ in environmental water samples. In our investigations we used natural water samples collected from the eastern part of Poland, the Bystrzyca River and Lake Zemborzyce. After sampling and before analysis the samples were stored in polypropylene bottles at a temperature of $6^{\circ} \mathrm{C}$. Based on our previous studies, in order to carry out direct voltammetric measurements of the analyzed waters, before measurements were made, the samples were mixed with Amberlite XAD-7 resin in order to remove organic substances, such as surface active substances and humic substances (Grabarczyk and Wardak, 2014; Grabarczyk and Wasąg, 2015, 2016; Wasąg and Grabarczyk, 2016). The process consisted of taking 2 $\mathrm{mL}$ of the analyzed water sample and $1 \mathrm{~mL}$ of acetate buffer $(\mathrm{pH}=5.0)$ and diluting it with distilled water to $10 \mathrm{ml}$ and then mixing for $5 \mathrm{~min}$ with the resin. After that the resin was sedimented and a suitable volume of the solution from over the resin was withdrawn and fed into the cell where the voltammetric measurement was carried out. The voltammograms recorded for the Bystrzyca River and Lake Zemborzyce water samples did not exhibit any $\mathrm{Ga}$ (III) and In(III) signal, which showed that the concentrations of these metals were below the detection limit of the proposed procedure. Therefore, in order to confirm the accuracy of the developed procedure, the analyzed samples were fortified with gallium and indium and recovery studies were performed. Three replicate determinations of each sample 


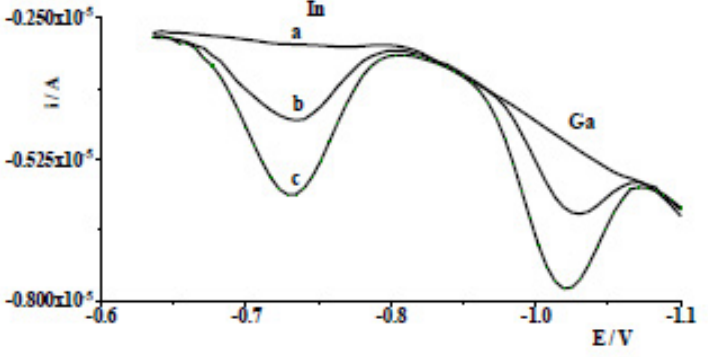

Fig. 6. Voltammograms obtained in over the course of the In(III) and $\mathrm{Ga}(\mathrm{III})$ determination of the Bystrzyca river sample: (a) diluted five times; (b) as (a) $+5 \times 10^{-7} \mathrm{~mol}^{-1} \mathrm{In}(\mathrm{III})$ and $\mathrm{Ga}(\mathrm{III})$; (c) as (a) $+1 \times 10^{-6} \mathrm{~mol} \mathrm{l}^{-1} \mathrm{In}(\mathrm{III})$ and $\mathrm{Ga}(\mathrm{III})$.

containing $2 \times 10^{-7} \mathrm{~mol} \mathrm{l}^{-1} \mathrm{Ga}$ (III) and In(III) produced average recovery values ranging from 95.3 to $98.7 \%$ with a relative standard deviation (RSD) of $5.2 \%$ for gallium and average recovery values ranging from 94.3 to $97.6 \%$ with a relative standard deviation (RSD) of $5.0 \%$ for indium. The typical voltammograms obtained during the analysis of Bystrzyca river water are presented in Fig. 6 .

\section{CONCLUSIONS}

1. The method of simultaneous determination of $\mathrm{Ga}(\mathrm{III})$ and $\mathrm{In}(\mathrm{III})$ is simple, responsive and cost effective, these factors distinguish it from the other procedures described in the literature and designed for the simultaneous quantification of gallium and indium.

2. The developed procedure may be used for the direct determination of gallium and indium in environmental water samples.

3. The satisfactory results of the analysis of real samples imply a promising application of the recommended procedure for monitoring the environment, which is necessary to evaluate the soil-plant system.

Conflict of interest: The Authors do not declare conflict of interest.

\section{REFERENCES not cited in the text}

Alfantazi A.M., and Moskalyk R.R., 2003. Processing of indium: a review. Miner. Eng., 16, 687-694.

Bermejo-Barrera P., Martinez-Alfonso N., and BermejoBarrera A., 2001. Separation of gallium and indium from ores matrix by sorption on Amberlite XAD-2 coated with PAN. Fresenius J. Anal. Chem., 369, 191-194. https://doi. org/10.1007/s002160000605

Choua W.L., Wang C.T., Yanga K.C., and Huanga Y.H. J., 2008. Removal of gallium (III) ions from acidic aqueous solution by supercritical carbon dioxide extraction in the green separation process. J. Hazard. Mater., 160, 6-12. https://doi. org/10.1016/j.jhazmat.2008.02.073

Daalkhaijav U., Yirmibesoglu O.D., Walker S., Menguc Y., 2018. Rheological modification of liquid metal for additive manufacturing of stretchable electronics. Adv. Mater. Technol., 3, Article Number: 1700351. https://doi.org/10.1002/admt. 201700351
Font O., Querol X., Juan R., Casado R., Ruiz C.R., and LopezSoler A., Coca P., and García Peña F., 2007. Recovery of gallium and vanadium from gasification fly ash. J. Hazard Mater., 139, 413-423. https://doi.org/10.1016/j.jhazmat. 2006.02.041

Grabarczyk M., and Wardak C., 2014. New voltammetric strategy for sensitive and selective determination of gallium using a cupferron as a complexing agent. J. Environ. Sci. Health, Part A, 49, 1142-1148. https://doi.org/10.1080/1093 4529.2014.897156

Grabarczyk M. and Wasąg J., 2015. Determination of trace amounts of $\mathrm{Ga}(\mathrm{III})$ by adsorptive stripping voltammetry with in situ plated bismuth film electrode. Talanta, 144, 1091-1095. https://doi.org/10.1016/j.talanta.2015.07.083

Grabarczyk M. and Wasąg J., 2016. Ultratrace determination of indium in natural water by adsorptive stripping voltammetry in the presence of cupferron as a complexing agent. J. Electrochem. Soc., 163, H218-H222. https://doi.org/ 10.1149/2.1001603jes

Hayashibe Y., Kurosaki M., Takekawa F, and Kuroda R., 1989. Determination of traces of gallium and indium in ores by electrothermal-atomization atomic absorption spectrometry with matrix modification. Microchim. Acta, II, 163-171. https://doi.org/10.1007/bf01244593

Królicka A., Bobrowski A., Kalcher K., Mocak J., Svancara I., and Vytras K., 2003. Study on catalytic adsorptive stripping voltammetry of trace cobalt at bismuth film electrodes. Electroanalysis, 15, 1859-1863. https://doi.org/10.1002/ elan.200302763

Królicka A., Pauliukaite R., Svancara I., Metelka R., Bobrowski A., Norkus E., Kalcher K., and Vytras K., 2002. Bismuthfilm-plated carbon paste electrodes. Electrochem. Commun., 4, 193-196. https://doi.org/10.1007/s00216-002-1569-3

Liu H.M., Jiang J.K., and Lin Y.H., 2012. Simultaneous determination of gallium(III) and indium(III) in urine and water samples with cloud point extraction and by inductively coupled plasma optical emission spectrometry. Anal. Letter., 45, 2096-2107. https://doi.org/10.1080/00032719.2012.68 0088

Medvecky L. and Briancin J., 2002. Possibilities of simultaneous determination of indium and gallium in binary InGa alloys by anodic stripping voltammetry in acetate buffer. Chem. Pap., 58, 93-100.

Merian E., Anke M., Ihnat M., and Stoeppler M., 2004. Elements and their compounds in the environment. VileyVCH Verlag GmbH and Co. KGaA, Weinheim. https://doi. org/10.1002/9783527619634

Orians K.J. and Boyle E.A., 1993. Determination of picomolar concentrations of titanium, gallium and indium in sea water by inductively coupled plasma mass spectrometry following an 8-hydroxyquinoline chelating resin preconcentration. Anal. Chim. Acta, 282, 63-74. https://doi.org/10.1016/00032670(93)80352-1

Petovar B., Xhanari K., and Finsgar M., 2018. A detailed electrochemical impedance spectroscopy study of a bismuthfilm glassy carbon electrode for trace metal analysis, Anal. Chim. Acta, 1004, 10-21. https://doi.org/10.1016/j. aca.2017.12.020

Prat M.D., Compano R., Granados M., and Miralles E., 1996. 
Liquid chromatographic determination of gallium and indium with fluorimetric detection. J. Chromat., A, 746, 239-245. https://doi.org/10.1016/0021-9673(96)00343-3

Saberyan K., Zolfonoun E., Shamsipur M., and SalavatiNiasari M., 2009. Separation and preconcentration of trace gallium and indium by Amberlite XAD-7 resin impregnated with a new hexadentates naphthol-derivative Schiff base. Sep. Scien. Technol., 44, 1851-1868. https://doi. org/10.1080/01496390902775257

Singh V.K., Agnihotri N.K., Singh H.B., Sharma R.L., 2001. Simultaneous determination of gallium(III) and indium(III) by derivative spectrophotometry. Talanta, 55, 799-806. https://doi.org/10.1016/s0039-9140(01)00507-0

Urbanova V., Bartoŝ M., Vytras K., and Kuhn A., 2010. Porous bismuth film electrodes for signal increase in anodic stripping voltammetry. Electroanalysis, 22, 1524-1530. https:// doi.org/10.1002/elan.200970016

Wang J., Lu J., Hocevar S.B., and Farias P.A.M., 2000. Bismuth-coated carbon electrodes for anodic stripping voltammetry. Anal. Chem., 72, 3218-3222. https://doi.org/ 10.1021/ac000108x

Wang J., Lu J., Kirgoz U.A., Hocevar S.B., and Ogorevc B., 2001. Insights into the anodic stripping voltammetric behavior of bismuth film electrodes. Anal. Chim. Acta, 434, 29-34. https://doi.org/10.1016/s0003-2670(01)00818-2

Wasąg J. and Grabarczyk M., 2016. Adsorptive stripping vol- tammetry of In(III) in the presence of cupferron using an in situ plated bismuth film electrode. Anal. Method., 8, 36053612. https://doi.org/10.1039/c6ay00621c

Węgiel K., Grabarczyk M., Kubiak W.W., and Baś B., 2017. A reliable and sensitive voltammetric determination of $\mathrm{Mo}(\mathrm{VI})$ at the in situ renovated bismuth bulk annular band electrode. J. Electrochem. Soc., 164, H352-H357. https:// doi.org/10.1149/2.1161706jes

Zaki M.T.M. and El-Didamony A.M., 1988. Determination of gallium and indium with haematoxylin in a micellar medium. Analyst, 113, 1277-1281. https://doi.org/10.1039/ an9881301277

Zatopa A., Walker S., and Menguc Y., 2018. Fully Soft 3D-Printed Electroactive Fluidic Valve for Soft Hydraulic Robots. Soft Robotics, https://doi.org/10.1089/soro.2017. 0019

Zhao Z., Yang Y., Xiao Y., and Fan Y., 2012. Recovery of gallium from Bayer liquor: A review. Hydrometallurgy, 125-126, 115-124. https://doi.org/10.1016/j.hydromet.2012.06.002

Zidaric T., Jovanovski V., and Hocevar S.B., 2018. Nanostructured bismuth film electrode for detection of progesterone, 18, 4233; doi:10.3390/s18124233, 1-7. https://doi. org/10.3390/s18124233 